\title{
Development of mycorrhizal soybean grown in copper- contaminated soil
}

\section{Desenvolvimento da soja micorrízada cultivada em solo contaminado com cobre}

\author{
Daiane Sartori Andreola ${ }^{1 *}$; Juliano de Oliveira Stumm²; Daniel Erison Fontanive ${ }^{1 ;}$ \\ Djavan Antônio Coinaski²; Ricardo Turchetto3; Robson Andreazza4; Clovis Orlando \\ da Ros $^{5}$; Rodrigo Ferreira da Silva ${ }^{6}$
}

\section{Highlights}

Heavy metals in the soil influence arbuscular mycorrhizal fungi.

Copper contamination levels cause a linear decrease in soybean development.

Soybean yield is reduced in heavy metal-contaminated soils.

Soybean inoculated with arbuscular mycorrhizae has a lower copper translocation rate.

The yield of mycorrhizal soybean is higher in copper-contaminated soils.

\section{Abstract}

High concentrations of copper in the soil are toxic to the development of plants and microorganisms. The aim of this study was to select arbuscular mycorrhizal fungi efficient for the development and yield of soybeangrown in copper-contaminated soil. The experiment was laid out in a completely randomized design with a $7 \times 4$ factorial arrangement corresponding to seven rates of copper $(0,80,160,240,320$, 400 , and $480 \mathrm{mg} \mathrm{kg}^{-1}$ of soil) and four inocula (uninoculated control and three mycorrhizal fungi, namely, Acaulospora colombiana, Dentiscutata heterogama and Rhizophagus clarus), in seven replicates. Shoot height; collar diameter; number of grains per plant; shoot and root-system dry mass; leaf area; specific

1 Masters Studants of the Postgraduat Program in Agronomy, Agriculture and Environment, Universidade Federal de Santa Maria, UFSM, Frederico Westphalen, RS, Brazil. E-mail: dayaandreola@hotmail.com; danielfontanive76@ gmail.com

2 Masters in Agronomy, UFSM, Frederico Westphalen, RS, Brazil. E-mail:julianoostumm@gmail.com; djavan_coinaski@ hotmail.com

3 Masters Studant of the Postgraduat Program in Science and Environmental Technology, UFSM, Frederico Westphalen, RS, Brazil. E-mail: ricardoturchetto10@gmail.com

4 Prof. PhD., Departament of Environmental and sanitary engineering, center for Engineering, Graduate Program in Enviromental Science and Territorial Development and Agroindustrial Systems, Universidade Federal de Pelotas, UFPel, Pelotas, RS, Brazil. E-mail: robson.andreazza@ufpel.edu.br

5 Prof. Dr., Departament of Agronomic and Environmental Sciences, Graduate Program in Agronomy, Agriculture and Environment and Program in Science and Environmental Technology, UFSM, RS, Brazil. E-mail: clovisdaros@gmail.com

6 Prof. Dr., Departament ofAgronomic and Environmental Sciences, Graduate Program in Science and Environmental Technology, UFSM, RS, Brazil. E-mail: rodrigosilvaufsm@gmail.com

* Author for correspondence

Received: Apr. 08, 2021 - Approved: July 18, 2021 
root surface; copper content and accumulation in the shoots, roots, and grain; chlorophyll parameters; and mycorrhizal colonization percentage were evaluated. Inoculation with the arbuscular mycorrhizal fungi Acaulospora colombiana, Dentiscutata heterogama and Rhizophagus clarus increases the phenological and physiological parameters of soybean and its yield when grown in soil contaminated with up to $480 \mathrm{mg}$ $\mathrm{kg}^{-1}$ of copper applied to the soil. The Rhizophagus clarus isolate provides greater development and yield in soybean grown in soil contaminated with up to $480 \mathrm{mg} \mathrm{kg}^{-1}$ of copper applied to the soil, as compared with the other isolates.

Key words: Arbuscular mycorrhizae. Heavy metal. Glycine max.

\section{Resumo}

O cobre em elevada concentração no solo torna-se tóxico ao desenvolvimento das plantas e microrganismo. O trabalho objetivou selecionar fungos micorrízicos arbusculares eficientes para o desenvolvimento e produtividade da soja cultivada em solo contaminado com cobre. O delineamento experimental foi em Inteiramente casualizado em arranjo fatorial $7 \times 4$, sendo, sete doses de cobre $(0,80,160,240,320,400$ e $480 \mathrm{mg}$ de cobre $\mathrm{kg}^{-1}$ de solo), quatro inóculos (testemunha sem inoculação e três fungos micorrízicos: Acaulospora colombiana, Dentiscutata heterogama e Rhizophagus clarus), com 7 repetições. Avaliou-se a altura da parte aérea, diâmetro do colo, número de grão por planta, massa seca da parte aérea e sistema radicular, área foliar, área superficial específica de raízes, teores e acúmulo de cobre na parte aérea, radicular e no grão, parâmetros da clorofila, e porcentagem de colonização micorrízica. A inoculação com fungos micorrízicos arbusculares Acaulospora colombiana, Dentiscutata heterogama, Rhizophagus clarus aumenta os parâmetros fenológicos e fisiológicos da soja e a sua produtividade soja em solo contaminado com até $480 \mathrm{mg} \mathrm{kg}^{-1}$ de cobre aplicado no solo. O isolado Rhizophagus clarus promove maior desenvolvimento da soja e aumenta sua produtividade em solo contaminado com até $480 \mathrm{mg} \mathrm{kg}^{-1} \mathrm{de}_{\text {cobre }}$ aplicado no solo em relação aos demais isolados.

Palavras-chave: Metal pesado. Micorrizas Arbusculares. Glycine max.

\section{Introduction}

Agricultural and industrial activities can increase the amount of copper $(\mathrm{Cu})$ in the soil, affecting plants, the microbial population and biological activity in the soil (Silva, Rocha, Rocha, \&Sousa, 2018). The mainanthropogenic sources of $\mathrm{Cu}$ in the soil are arbitrary use of pesticides and fungicides, irrigation with wastewater, industrialization, urbanization (Marques, Silva, Mantovani, Pereira, \& Souza, 2018) and the use of organic fertilizers such as swine manure, which can accumulate in the soil when used continuously for agricultural purposes. Thus, once the soil $\mathrm{Cu}$ content exceeds $200 \mathrm{mg} \mathrm{kg}^{-1}$, an intervention will be necessary in agricultural areas (Conselho Nacional do Meio Ambiente [CONAMA], 2009).

Plants grown in soils with a high $\mathrm{Cu}$ content can accumulate this metal in their tissues and develop toxicity symptoms (Tiecher et al., 2018). An excess of this element can lead to inhibited nutrient absorption as well as reduced photosynthetic rates and plant growth. In the roots, Cu can damage their structures, reducing the absorption of water and nutrients from the soil and, consequently, plant growth (Ambrosini et al., 2016). In 
soybean (Glycine max (L.) Merrill), Cu toxicity causes necrotic spots on the edge of leaflets from older leaves, which then advance to the younger leaves.

Soybean is important for the agroindustry in Brazil, which is ranked first in the production of the oilseed, having achieved revenues of USD 40.64 billion in 2020 (Companhia Nacional de Abastecimento [CONAB], 2020). Different foods are produced from soybean, e.g., oil, milk, margarine, cheese, sauces, textured protein, flour and meal, the latter of which is used as animal feed (Gondin, 2019). The increased use of Cu-containing inputs on the soil raises questions about the feasibility of growing soybean associated with microorganisms in soil contaminated with this metal. Excess $\mathrm{Cu}$ in plants can lead to physiological and biochemical disturbances, inhibiting their development (Gautam, Anjani, \& Srivastava, 2016). When in excess, $\mathrm{Cu}$ is absorbed by the soybean plant, causing an imbalance in leaf tissue concentrations and, thus, negative impacts on yield (Bedin, 2018).

Mycorrhizal fungi establish a mutualistic symbiosis termed 'mycorrhizal' (Brundrett, Bougher, Dell, Grove, \& Malajczuk, 1996). These fungi possess mechanisms that make it possible to change the bioavailability of elements that are toxic to plants, resulting in decreased uptake, accumulation, or translocation of heavy metals. Therefore, they indirectly provide improvements in nutritional status (Ferreira et al., 2016), plant nutrition and resistance of the root system (FolliPereira, Meira-Haddad, Bazzolli, \& Kasuya, 2012), as their fungal structures constitute a biological barrier to metal toxicity. Results of research in uncontaminated soil revealed that mycorrhization in soybean increases shoot and root biomass, number of nodules, nodule biomass and phosphorus contents (Pereira et al., 2013). In this scenario, a persisting doubt is whether mycorrhizal fungi promote the development and yield of soybean grown specifically in Cu-contaminated soil. The present study was thus developed to select arbuscular mycorrhizal fungi (AMF) efficient for the development and yield of Glycine max L. grown in soil contaminated with $\mathrm{Cu}$.

\section{Materials and Methods}

The experiment was conducted in a protected environment, in a greenhouse belonging to the Department of Agronomic and Environmental Sciences at the Federal University of Santa Maria (UFSM), Frederico Westphalen Campus, between October 2019 and February 2020, for a period of 120 days.

The soil used in the experiment was characterized as a Red Oxisol (Santos et al., 2018), which was collected in an agricultural production area from the $0-20 \mathrm{~cm}$ layer, with $70 \%$ clay texture. To be used in this experiment, the soil was mixed with medium sand at the ratio of $50: 50(\mathrm{v}: \mathrm{v})$ to obtain a texture of approximately $35 \%$ clay. Next, the texture was determined according to Empresa Brasileira de Pesquisa Agropecuária [EMBRAPA] (2017) system; chemical analysis of the substrate was carried out following Tedesco, Gianello, Bissani, Bohnen and Volkweiss, (1995) (Table 1); and correction was performed with dolomitic limestone (100\% relative TNP) to achieve a base saturation level greater than $65 \%$, as recommended for the soybean crop (Sociedade Brasileira de Ciência do Solo [SBCS], 2016). 
Table 1

Physicochemical characterization of the soil used to implement the experiment with the soybean crop

\begin{tabular}{|c|c|c|c|c|c|c|c|c|c|}
\hline & Texture* & $\mathrm{pH}$ & OM & $P$ & K & $\mathrm{Mg}$ & $\mathrm{Al}+\mathrm{H}$ & $\mathrm{Cu}$ & $\mathrm{Zn}$ \\
\hline \multirow{2}{*}{ Soil + sand } & $\%$ & $1: 1$ & $\%$ & ----- & $\mathrm{ng} / \mathrm{d}$ & ----- & & \multicolumn{2}{|c|}{----mg/dm³ --- } \\
\hline & $34 \%$ & 5.8 & 0.8 & 1.8 & 26.4 & 1.3 & 2.5 & 0.8 & 0.1 \\
\hline
\end{tabular}

* Texture $=\%$ clay, determined by the test tube method (EMBRAPA, 2017).

A completely randomized experimental design was implemented with a $7 \times 4$ factorial arrangements corresponding to seven rates of $\mathrm{Cu}(0,80,160,240,320,400$, and 480 mg kg-1 of soil) and four inocula (control, without inoculation; and three mycorrhizal fungi, namely, Acaulospora colombiana, Dentiscutata heterogama and Rhizophagus clarus), in seven replicates. The AMF isolates were acquired from the International Glomeromycota Culture Collection (CICG) of the Mycorrhizae Laboratory at the Regional University of Blumenau - SC (FURB).

Dolomitic limestone $(100 \%$ relative TNP) was added for soil correction, as recommended for the soybean crop so that base saturation exceeded $65 \%$. After 30 days of lime addition, with the stabilization of $\mathrm{pH}$, the soil was sterilized in an autoclave at a temperature of $121^{\circ} \mathrm{C}$ in three cycles of 30 min. The soil was then contaminated with $\mathrm{Cu}$, with the rates applied 30 days before sowing, in the form of Cu sulfate solution (CuSO $4.5 \mathrm{H} 2 \mathrm{O}$ ), which was homogenized in the soil by shaking in a plastic bag.

The plants were grown in plastic pots with a capacity of $5 \mathrm{~L}$, which were filled with $4.5 \mathrm{~kg}$ of soil. Five seeds of soybean cultivar 5917 IPRO were sown in each pot after being disinfested with $2 \%$ sodium hypochlorite for 15 min and washed in running water for 5 min. Thinning was performed eight days after germination, leaving one plant per pot until the end of the experiment. Water irrigation was applied daily through a drip irrigation system, maintaining soil moisture at $80 \%$ of field capacity.

At the end of the experiment, shoot height was measured using a graduated ruler, from the top of the plants to the insertion of the last trefoil; collar diameter using a Black Jack Tools ${ }^{\circledR}$ digital caliper; and root volume (RV) with a graduated beaker. Number of pods, number of grains per plant, 1000-grain weight, leaf dry mass (LDM), stem dry mass (STDM), root system dry mass (RDM) and shoot dry mass (SDM) were also measured. To determine the last two variables, the root system and the shoots were separated in the collar region of the plant and oven-dried at $60 \pm 1{ }^{\circ} \mathrm{C}$ until reaching constant weight. Then, the fractions were weighed on an analytical scale and the total dry mass (TDM) was calculated as the sum of RDM and SDM.

The roots were washed in running water over $0.5-\mathrm{mm}$ mesh sieves and dried on blotting paper. Then, RV was determined by the method of water displacement in the beaker, adapted from the methodology used in soils by EMBRAPA (2017). Leaf area was determined by the method of discs of known area (Benincasa, 1988). 
At the R2 stage (full flowering), the relative chlorophyll index $(\mathrm{RCl})$ in the leaves was determined using a portable chlorophyll meter (CFL 1030, ClorofiLOG ${ }^{\circledR}$, Falker, Porto Alegre, Brazil) (FALKER, 2008), which instantly provides results in dimensionless units called $\mathrm{RCl}$ values. The reading was taken at three wavelengths, with two emitters in the red band (one near the peak of each chlorophyll: a and b) and one in the near-infrared band.
The roots were cleared and stained with Trypan Blue (0.05\%) to visualize structures such as vesicles, arbuscules or hyphae under a stereomicroscope and an optical microscope (60x) (Brundrett et al., 1996). The mycorrhizal colonization (MC) percentage was determined by the gridline intersection method (Brundrett et al., 1996), whereby the total number of colonized roots and the total number of roots were counted and the formula below was applied:

$$
\frac{\mathrm{MC}(\%)=\text { Total } \mathrm{n} \text { of colonized roots } \times 100}{\text { Total } \mathrm{n} \text { of roots }}
$$

The dry mass of roots and shoots was ground in a Wiley mill with a 10-mesh sieve to determine the $\mathrm{Cu}$ contents in the plant tissue by nitric-perchloric digestion (3:1) followed by atomic absorption spectrophotometry (Miyazawa, Pavan, Muraoka, Carmo, \& Melo, 2009). For the soil, a sample of each treatment was collected and the pseudo-total contents were determined following the 3050b methodology (United States Environmental Protection Agency [USEPA], 1996).

Results were subjected to analysis of variance to identify the significance of the interaction between the factors. When it was detected, regression analysis was performed for the quantitative factors, within each level of the qualitative factor. When non-significant, the simple effects were decomposed by regression analysis (quantitative) and test of means (qualitative), by the Scott-Knott test (at $5 \%$ error probability), using SISVAR software (Ferreira, 2019).

\section{Results and Discussion}

There was an interaction effect between the AMF inocula and Cu rates applied to the soil on the number of soybean grains and 1000-grain weight (Figure 1). The number of grains per plant decreased linearly with the increasing Cu rates but was significantly higher with inoculation, where the $R$. clarus inoculum provided superior results (Figure 1A). Malfatti and Cruz (2019) found greater grain mass in soybean plants inoculated with R. Clarus AMF. In contrast, Vieira, Furmigare, Teixeira and Colen, (2015) reported an increase in shoot dry mass and grain dry mass, which contributed directly to the final yield of soybean. This is because plants inoculated with mycorrhizal fungi have increased tolerance to heavy metals in contaminated soils (Cabral, Siqueira, Soares, \& Pinto, 2010). 
A)

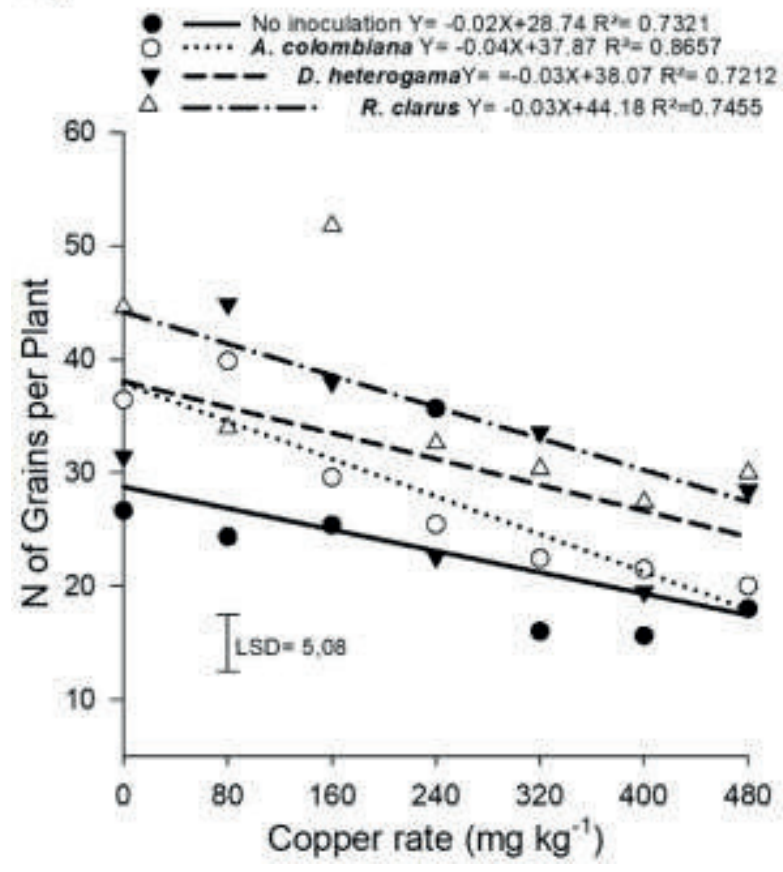

B)

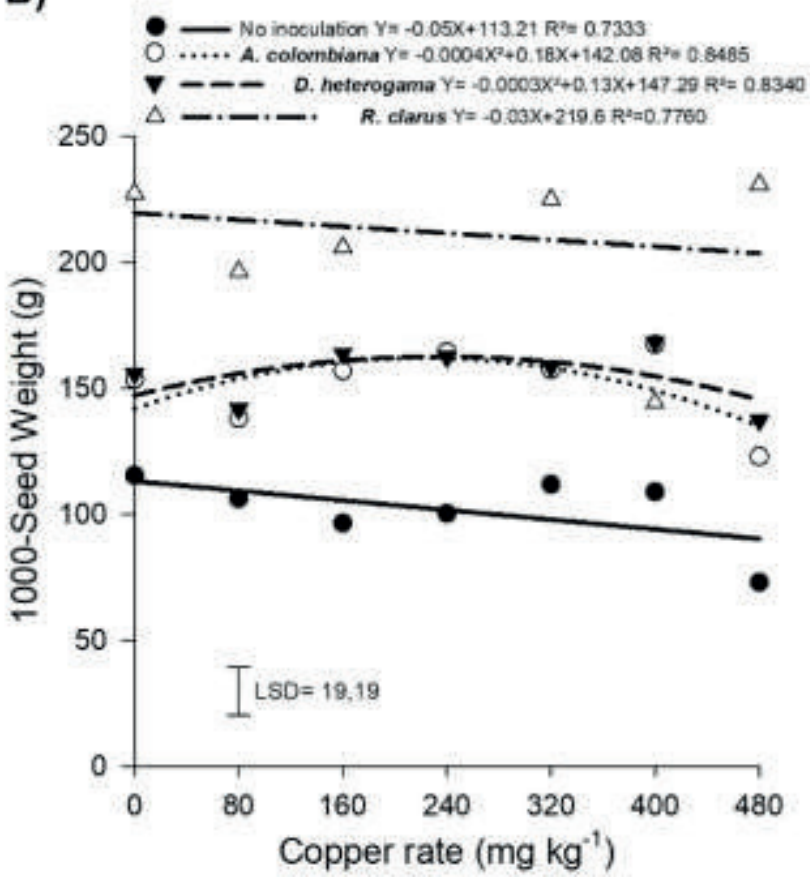

Figure 1. Number of grains and 1000-grain weight of soybean without and with inoculation with arbuscular mycorrhizal fungi in soil contaminated with copper rates.

Thousand-grain weight was significantly higher with the inoculation treatments, with the $R$. clarus isolate standing out among the inoculate (Figure 1B). Arbuscular mycorrhizal fungi are one of the most valuable components of the soil biota due to their positive nutritional effects on crop yield (Berude, Almeida, Cabanêz, \& Amaral, 2015), and their fungal structures can act as a barrier, retaining metals and thus reducing their toxicity. In the soybean crop, AMF increase plant growth and yield. Increases of around $244 \mathrm{~kg} \mathrm{ha}^{-1}$ in soybean grain have been observed in the field as a result of arbuscular mycorrhiza (Miranda \& Miranda, 1997). This result demonstrates that soybean plants inoculated with AMF produce more grains and have a higher 1000-grain weight, even in soil contaminated with $\mathrm{Cu}$, which will vary according to the species of inoculated fungus.
There was no significant interaction effect between inoculate and Cu rates on plant height, shoot dry mass (SDM), root dry mass (RDM), root volume (RV), leaf area or number of pods. These variables were only affected separately by the Cu rate, with RV decreasing quadratically and the other parameters linearly (Figure 2). At concentrations higher than those necessary for optimal growth, $\mathrm{Cu}$ inhibits plant growth and prevents important cellular processes (Yruela, 2005), becoming toxic to plant growth. The results of this study corroborate those described by Silva (2019), where the height, root length, shoot and root dry mass of soybean plants decreased with increasing soil $\mathrm{Cu}$ contents, especially in sandy soils. 
A)

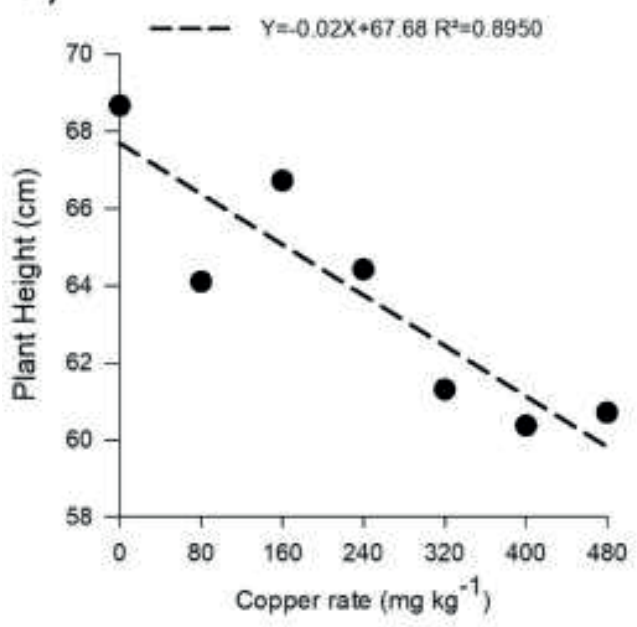

C)

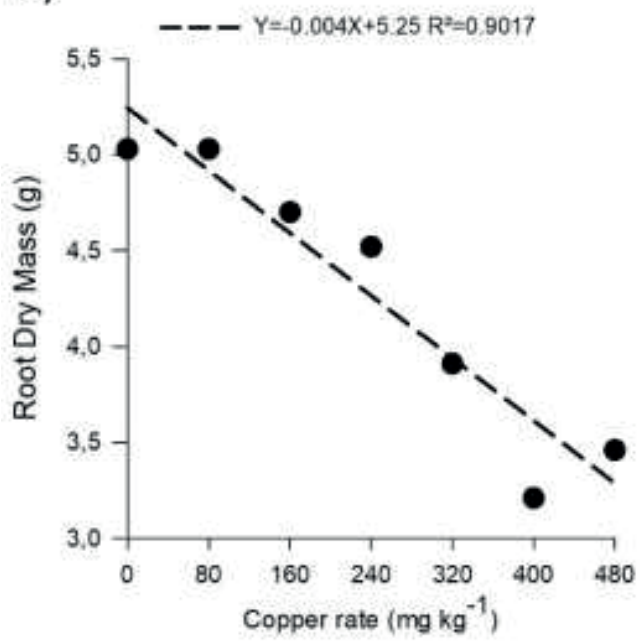

E)

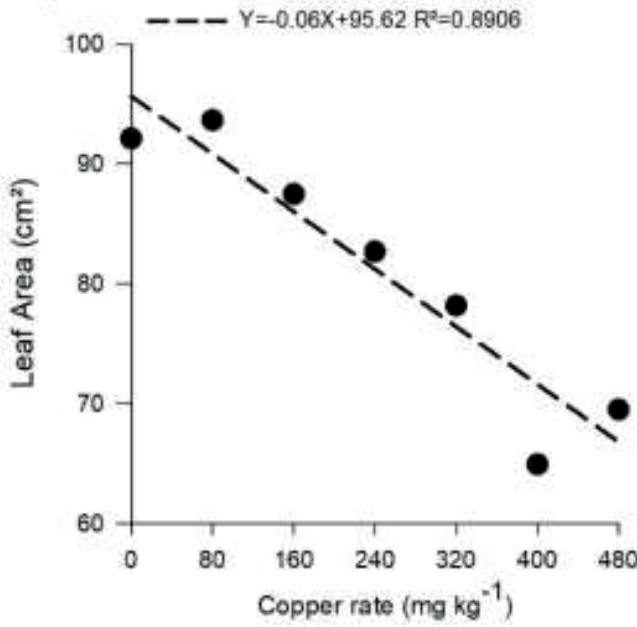

B)

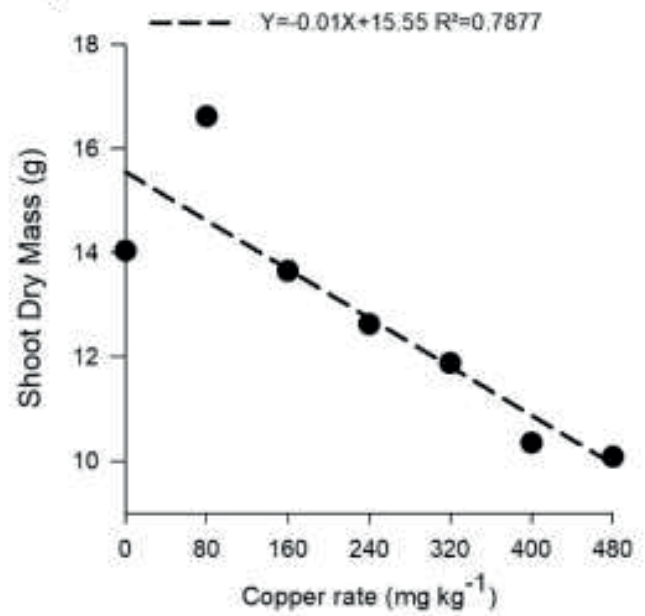

D)

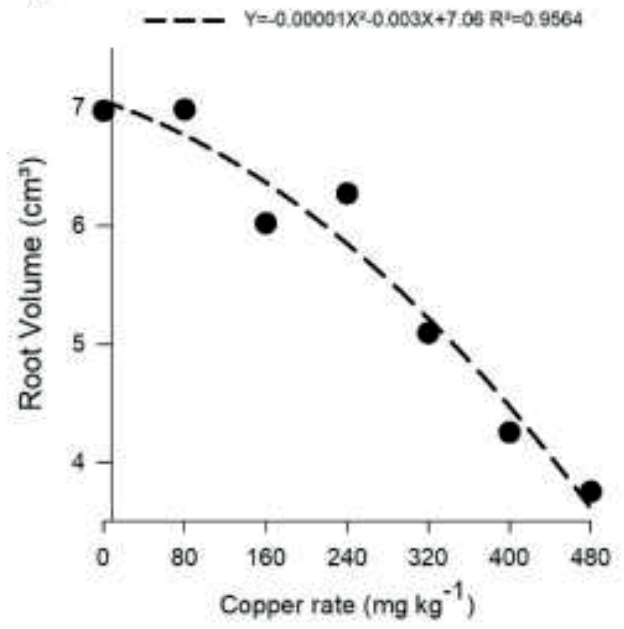

F)

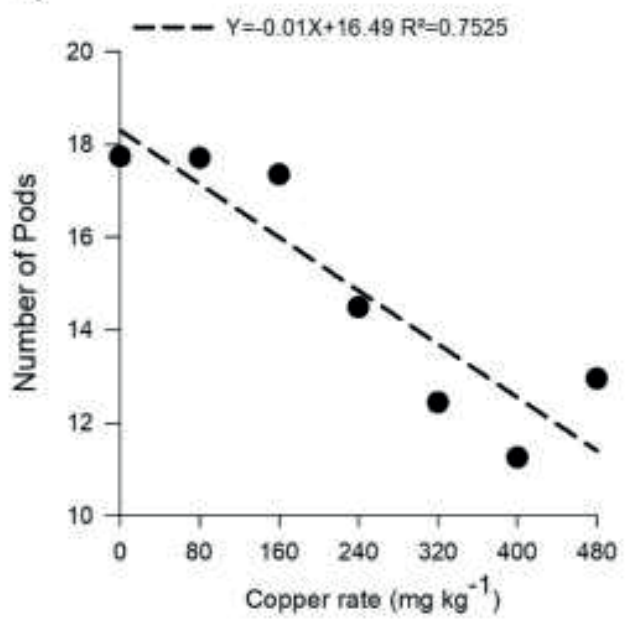

Figure 2. Plant height, shoot dry mass, root dry mass, root volume, leaf area and number of pods of soybean subjected to soil contaminated with copper rates. 
The inoculum factor alone had a significant effect on stem diameter, plant height, number of pods, chlorophyll $A$, chlorophyll B, total chlorophyll, leaf area, LDM, RV, STDM, SDM and RDM (Table 2). Inoculation with R. clarus provided significantly higher values than the other treatments for all these variables. The D. heterogamaand A. colombiana inoculate did not differ from each other, providing results superior to those obtained with the treatment without mycorrhiza (Table 2). Research results have shown that soybean plants subjected to mycorrhizal colonization produce 2.0 and 3.5 times more biomass than non-mycorrhizal ones (Fernández, Boem, \& Rubio, 2011). Inoculation with $R$. clarus stimulates the growth of soybean plants, increasing their height, STDM, SDM and RDM.

Table 2

Stem diameter (SD), plant height (PH), number of pods (NP), root volume (RV), stem dry mass (STDM), root dry mass (RDM), leaf dry mass (LDM), shoot dry mass (SDM), leaf area (LA) chlorophylls $A$ and $B$ and total chlorophyll of soybean plants subjected to inoculation treatments with arbuscular mycorrhizal fungi

\begin{tabular}{|ccccccc}
\hline Inoculation & SD $(\mathrm{mm})$ & PH $(\mathrm{cm})$ & NP $(\mathrm{n})$ & RV $(\mathrm{mL})$ & STDM $(\mathrm{g})$ & RDM $(\mathrm{g})$ \\
\hline No mycorrhiza & $5.28 \mathrm{C}$ & $50.61 \mathrm{C}$ & $11.36 \mathrm{C}$ & $4.64 \mathrm{C}$ & $5.77 \mathrm{~B}$ & $3.43 \mathrm{D}$ \\
\hline A. colombiana & $6.82 \mathrm{~B}$ & $64.02 \mathrm{~B}$ & $15.63 \mathrm{~B}$ & $5.77 \mathrm{~B}$ & $7.08 \mathrm{~B}$ & $4.46 \mathrm{~B}$ \\
\hline D. heterogama & $6.59 \mathrm{~B}$ & $62.33 \mathrm{~B}$ & $14.41 \mathrm{~B}$ & $5.52 \mathrm{~B}$ & $6.32 \mathrm{~B}$ & $4.08 \mathrm{C}$ \\
\hline R. clarus & $8.16 \mathrm{~A}$ & $77.75 \mathrm{~A}$ & $18.25 \mathrm{~A}$ & $6.79 \mathrm{~A}$ & $9.74 \mathrm{~A}$ & $5.21 \mathrm{~A}$ \\
\hline Inoculation & LDM (g) & SDM (g) & LA $\left(\mathrm{cm}^{2}\right)$ & Chlorophyll A & Chlorophyll B & Total chlorophyll \\
No mycorrhiza & $4.76 \mathrm{D}$ & $9.38 \mathrm{C}$ & $64.59 \mathrm{C}$ & $26.66 \mathrm{C}$ & $6.96 \mathrm{C}$ & $33.62 \mathrm{C}$ \\
\hline A. colombiana & $6.23 \mathrm{~B}$ & $13.09 \mathrm{~B}$ & $81.64 \mathrm{~B}$ & $32.50 \mathrm{~B}$ & $8.45 \mathrm{~B}$ & $40.96 \mathrm{~B}$ \\
\hline D. heterogama & $5.68 \mathrm{C}$ & $11.61 \mathrm{~B}$ & $81.59 \mathrm{~B}$ & $32.07 \mathrm{~B}$ & $8.05 \mathrm{~B}$ & $40.12 \mathrm{~B}$ \\
\hline R. clarus & $7.32 \mathrm{~A}$ & $17.12 \mathrm{~A}$ & $98.55 \mathrm{~A}$ & $39.52 \mathrm{~A}$ & $10.54 \mathrm{~A}$ & $50.11 \mathrm{~A}$
\end{tabular}

* Means followed by the same uppercase letter in the column do not differ by the Scott-Knott test (5\%).

Mycorrhizal association can increase the chlorophyll content of the leaves by providing greater tolerance to the stress caused on the plants (Colla et al., 2008), since hormonal, physiological and cellular changes take place, e.g. increase in chlorophyll content and photosynthetic rate (Maia, Costa, \& Santos, 2001). In the soybean crop, $R$. clarus and Gigaspora margarita increased growth, dry matter and photosynthetic area, resulting in higher amounts of photoassimilates, nutrients and crop yield. The results of this study indicate that the use of $R$. clarus inoculum was more efficient in the symbiosis in the soybean crop, inducing an increase in morphological and physiological parameters of the plant.

Copper accumulation in the shoots and in the root system of the soybean plants did not show to be significantly affected by the interaction between $\mathrm{Cu}$ rates and AMF inoculate, only by the $\mathrm{Cu}$ rates alone (Figure 3). The results indicated a quadratic increase in $\mathrm{Cu}$ accumulation in the shoots, which would reach $353 \mu \mathrm{g}$ per plant of $\mathrm{Cu}$ at the estimated Cu rate of $343 \mathrm{mg} \mathrm{kg}^{-1}$ of soil (Figure $3 \mathrm{~A}$ ), and in the root system, with $1349 \mu \mathrm{g}$ per plant of $\mathrm{Cu}$ reached at $363 \mathrm{mg} \mathrm{kg}^{-1} \mathrm{Cu}$ of soil (Figure 3B). The sensitivity of plants to $\mathrm{Cu}$ toxicity 
varies greatly, because, in most species, $\mathrm{Cu}$ accumulates in the roots, primarily damaging this part of the plant, which is not directly visible (McBride, 2001). Accumulation of this metal in the roots is one of the main tolerance strategies to prevent its translocation to the shoots (Cambrollé, García, Ocete, Figueroa, \& Cantos, 2013). There was no significant interaction between $\mathrm{Cu}$ rate and inoculation with AMF, but only significant single effects of Cu rates on the Cu contents in the shoot, root system and grain (Figure 3).
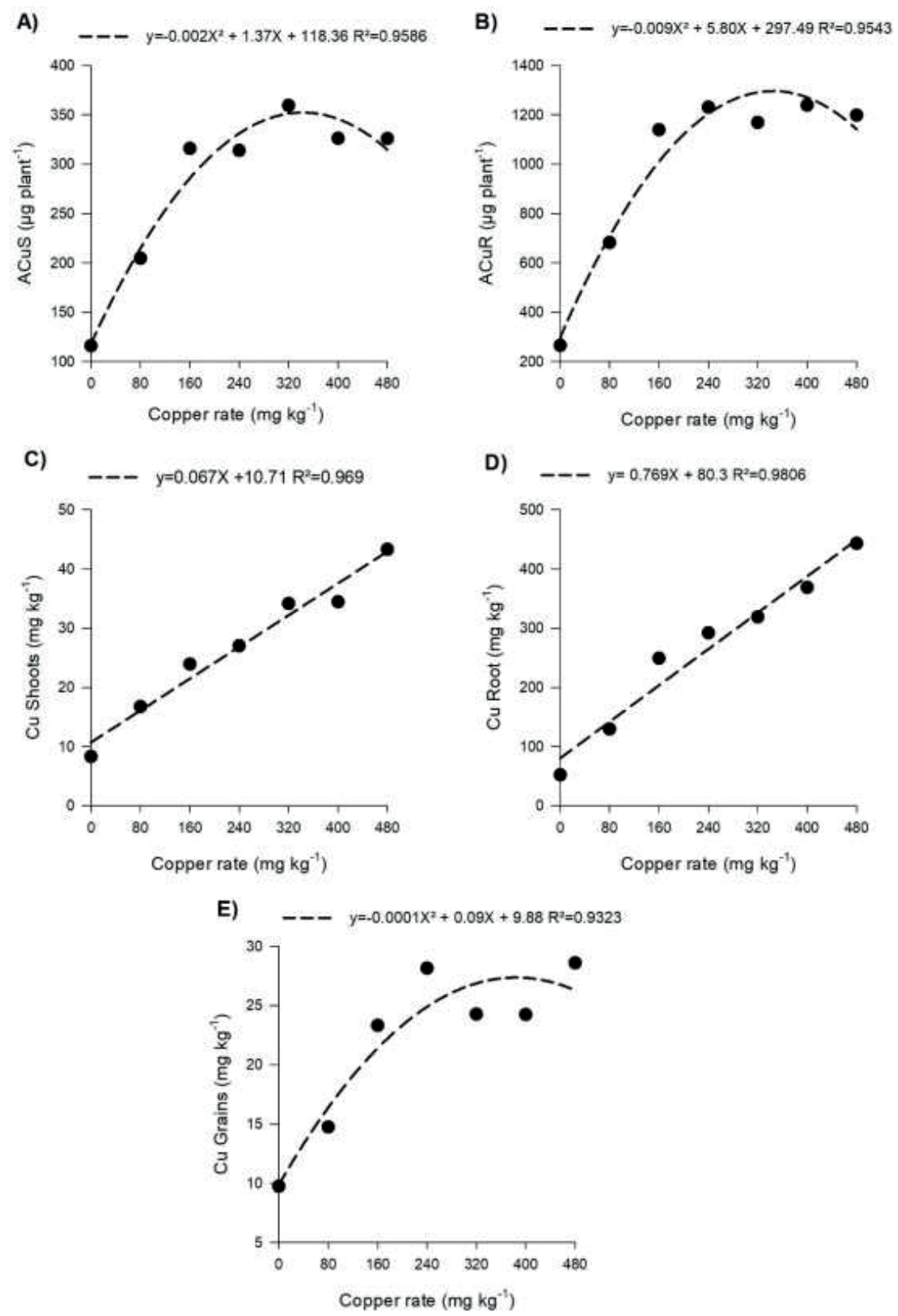

Figure 3. Accumulated copper content in the shoots (ACuS, A) and in the root system (ACuR, B); and copper content in the shoots $(C)$, root system (D) and grain (E) of soybean plants subjected to soil contaminated with copper rates. 
The Cu content of the shoots increased linearly with the $\mathrm{Cu}$ rates applied to the soil (Figure $3 \mathrm{C}$ ). In the roots, the Cu content formed a linear curve, with $433.1 \mathrm{mg} \mathrm{kg}-1$ at the highest tested rate (Figure 3D). It appears that the roots of soybean plants limit $\mathrm{Cu}$ translocation to the shoots (Silva, Vitti, \& Trevizam, 2007). This mechanism of tolerance to excess $\mathrm{Cu}$ by the roots results from the immobilization of $\mathrm{Cu}$ in the cell wall, elimination or restriction of absorption, compartmentalization in the vacuole with soluble complexes and formation of chelates at the cell-membrane interface and phytochelatins, which chelate heavy metals in cells, preventing intracellular damage (Seidel, Costa, \& Lana, 2009). According to Mantovani (2009), Cu concentrations above $20 \mathrm{~g} \mathrm{~kg} \mathrm{k}^{-1}$ in the shoot DM are considered toxic for some legume species.

The Cu content in the grain responded in a quadratic curve, whose maximum point was reached at the $\mathrm{Cu}$ rate of $357 \mathrm{mg} \mathrm{kg}^{-1}$ applied to the soil, resulting in $25.7 \mathrm{mg} \mathrm{kg}^{-1}$ of grain (Figure 3E). The literature reports 7.6 $\mathrm{mg} \mathrm{Cu} \mathrm{kg}{ }^{-1}$ in soybean grown in soils without Cu application (Magalhães, Megaioli, Freddi, \& Santos, 2016). The Health Surveillance Agency of Brazil established $10 \mathrm{mg} \mathrm{Cu} \mathrm{kg}^{-1} \mathrm{DM}$ as the maximum allowed limit for this chemical element in the grain (Agência Nacional de Vigilância Sanitária [ANVISA], 1998). Thus, there was a considerable increase in this metal in the grain when the soybean was grown under high rates of $\mathrm{Cu}$ in the soil.
Results revealed a significant interaction between the sources of variation for mycorrhizal colonization percentage, which was significantly higher (maximum of $19.2 \%$ at $150 \mathrm{mg} \mathrm{Cu} \mathrm{kg}^{-1}$ of soil) with $R$. clarus and which decreased linearly with inoculation using $A$. Colombiana and $D$. heterogama (Figure 4). The literature shows a certain preference of the plant in relation to AMF species, which differ in how and at what intensity they colonize the roots (Miranda, Vilela, \& Miranda, 2005). In studies carried out by Negrini (2017), $A$. colombiana was not efficient in improving the quality of eucalyptus seedlings, whereas this isolate largely colonizes the roots of strawberry, promoting root growth. The inoculum quality and compatibility of $R$. clarus for root colonization in soybean plants were also evidenced.

The presence of heavy metals at toxic concentrations in the soil influences $\mathrm{AMF}$, as they reduce spore germination, mycelial growth, colonization and sporulation (Klauberg, Siqueira, Moreira, Soares, \& Silva, 2005). However, the association between plant and AMF induces a beneficial effect on the plant in metal-contaminated soils, as they can increase its growth and reduce negative effects of stresses (Mathur, Sharma, \& Jajoo, 2018). The present results confirm this ability of mycorrhizal fungi, as the R. clarus isolate provided greater development and yield in soybean, even in soil contaminated with $\mathrm{Cu}$. 


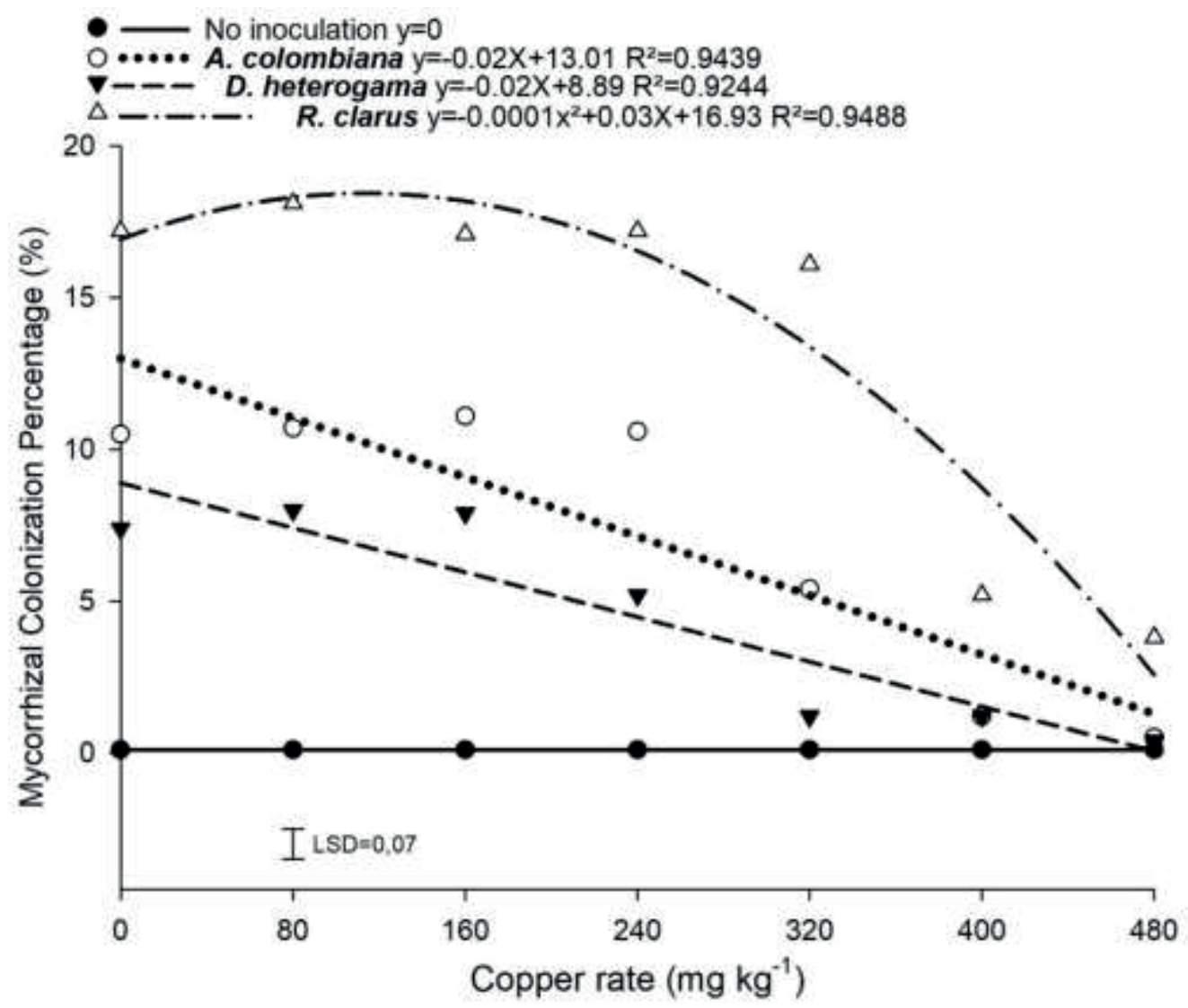

Figure 4. Mycorrhizal colonization percentage in soybean plants subjected to inoculation treatments in soil contaminated with copper rates.

\section{Conclusions}

Inoculation with the arbuscular mycorrhizal fungi Acaulospora colombiana, Dentiscutata heterogama and Rhizophagus clarus increases the phenological and physiological parameters of soybean and its yield in soil contaminated with up to $480 \mathrm{mg}$ $\mathrm{kg}^{-1}$ of copper applied to the soil.

The Rhizophagus clarus isolate provides greater development and yield in soybean grown in soil contaminated with up to $480 \mathrm{mg} \mathrm{kg}^{-1}$ of copper applied to the soil, as compared with the other isolates.

\section{References}

Agência Nacional de Vigilância Sanitária (1998). Portaria $N^{\circ} 685$, de 27 de agosto de 1998. Regulamento técnico: princípios gerais para o estabelecimento de níveis máximos de contaminantes químicos em alimentos. Diário Oficial da União, Poder Executivo, de 28 de agosto de 1998.

Ambrosini, V. G., Soriani, H. H., Rosa, D. J., Tiecher, T. L., Girotto, E., Simão, G. D., \& Brunetto, G. (2016). Impacto do excesso de cobre e zinco no solo sobre videiras e plantas de cobertura. Bento Gonçalves, RS, EMBRAPA Uva e Vinho. (INFOTECA-E). 
Recuperado de http://www.infoteca. cnptia.embrapa.br/infoteca/handle/doc/ 1065884

Bedin, E. (2018). Aplicações foliares de cobre no manejo da ferrugem-asiática da soja. Dissertação de mestrado em Agronomia, Universidade de Passo Fundo, Passo Fundo, RS, Brasil. Recuperado de http://tede.upf.br/jspui/bitstream/tede/ 1665/2/2018EdevanBedin.pdf

Benincasa, M. M. (1988). Análise de crescimento de plantas: noções básicas. Jaboticabal: FUNEP. Recuperado de http://www.sidalc. net/cgi-bin/wxis.exe/?IsisScript=ACERVO. xis \&method=post $\&$ formato $=2 \&$ cantidad $=$ 1 \&expresion $=\mathrm{mfn}=002834$

Berude, M., Almeida, D., Riva, M., Cabanêz, P., \& Amaral, A. (2015). Micorrizas e sua importância agroecológica. Enciclopédia Biosfera, 11(22), 1-15. Recuperado de https://conhecer.org.br/ojs/index.php/ biosfera/article/view/1368/1308

Brundrett, M., Bougher, N., Dell, B., Grove, T., \& Malajczuk, N. (1996). Working with mycorrhizas in forestry and agriculture (vol. 32). Canberra: Australian Centre for International Agricultural Research. Recuperado de file:///C:/Users/danie/ Downloads/mn32_pdf_66358.pdf

Cabral, L., Siqueira, J. O., Soares, C. R. F. S., \& Pinto, J. E. B. P. (2010). Retenção de metais pesados em micélio de fungos micorrízicos arbusculares. Química Nova, 33(1), 25-29. doi: 10.1590/S0100-404220 10000100005

Cambrollé, J., García, J. L., Ocete, R., Figueroa, M. E., \& Cantos, M. (2013). Growth and photosynthetic responses to copper in wild grapevine. Chemosphere, 93(2), 294-301. doi: 10.1016/j.chemosphere.20 13.04 .080

Colla, G., Rouphael, Y., Cardarelli, M., Tullio, M., Rivera, C. M., \& Rea, E. (2008). Alleviation of salt stress by arbuscular mycorrhizal in zucchini plants grown at low and high phosphorus concentration. Biology and Fertility of Soils, 44(3), 501-509. doi: 10. 1007/s00374-007-0232-8

Companhia Nacional de Abastecimento (2020). Série histórica de produção. Recuperado de https://www. conab.gov. br/info-agro/safras/serie-historica-dassafras?start $=30$

Conselho Nacional do Meio Ambiente (2009). Resolução $n^{\circ}$ 420, de 28 de dezembro de 2009, retificada em 2012. DOU $\mathrm{n}^{\circ}$ 249, de 30/12/2009. Recuperado de https://cetesb.sp.gov.br/solo/wp-content/ uploads/sites/18/2014/12/CONAMA420-09.pdf

Empresa Brasileira de Pesquisa Agropecuária (2017). Manual de métodos de análise de solo (3a ed. rev. ampl.). Rio de Janeiro: EMBRAPA.

FALKER (2008). Automação agrícola. Manual do medidor eletrônico de teor clorofila (ClorofilOG/CFL 1030). Recuperado de https://www.falker.com.br/suporte-CFL 1030.php

Fernández, C. M., Boem, F. H. G., \& Rubio, G. (2011). Effect of indigenous mycorrhizal colonization on phosphorus acquisition efficiency in soybean and sunflower. Journal of Plant Nutrition and Soil Science, 174(4), 673-677. doi: 10.1002/ jpln.201000109 
Ferreira, D. F. (2019). Sisvar: a computer analysis system to fixed effects split plot type designs. Revista Brasileira de Biometria, 37(4), 529-535. doi: 10.28951/ rbb.v37i4.450

Ferreira, P. A. A., Silva, E. P., Armas, R. D., Lazzaretti, B. P., Melo, G. W. B., Zalamena, J., \& Soares, C. R. F. S. (2016). Estratégias de amenização da fitotoxidez de metais pesados em solos de vinhedos. (INFOTECA-E). Bento Gonçalves, RS, EMBRAPA Uva e Vinho. Recuperado de https://www.infoteca.cnptia.embrapa.br/ infoteca/handle/doc/1065886

Folli-Pereira, M. D. S., Meira-Haddad, L. S. A., Bazzolli, D. M. S., \& Kasuya, M. C. M. (2012). Micorriza arbuscular e a tolerância das plantas ao estresse. Revista Brasileira de Ciência do Solo, 36(6), 1663-1679. doi: 10.1590/S0100-06832012000600001

Gautam, S., Anjani, K., \& Srivastava, N. (2016). In vitro evaluation of excess copper affecting seedlings and their biochemical characteristics in Carthamus tinctorius L. (variety PBNS-12). Physiology and Molecular Biology of Plants, 22(1), 121129. doi: 10.1007/s12298-016-0339-1

Gondin, R. H. P. (2019). Industrialização da soja no Brasil. Trabalho de conclusão de curso em Engeharia Química. Universidade Federal de Uberlândia, Uberlândia, MG, Brasil. Recuperado de https://repositorio. ufu.br/handle/123456789/24266

Klauberg, O., F., Siqueira, J. O., Moreira, F. M. S., Soares, C. R. F. S., \& Silva, S. (2005). Ecologia, função e potencial de aplicação de FMAs em condições de excesso de metais pesados. In P. Vidal-Torrado, L. R. F. Alleoni, M. Cooper, A. P. Silva, \& E. J. Cardoso (Eds.). Tópicos em ciência do solo (vol. 4, pp. 85-144). Viçosa, MG, Universidade Federal de Viçosa, Sociedade Brasileira de Ciência do Solo.

Magalhães, W. A., Megaioli, T. G., Freddi, O. S., \& Santos, M. A. (2016). Quantificação de nutrientes em sementes de soja. Revista de Ciências Agroambientais, 13(2), 1-6. doi: 10.5327/rcaa.v13i2.1189

Maia, L. C., Costa, C. M., \& Santos, V. F. (2001). Mycorrhizal dependency of passion fruit (Passiflora edulis f. flavicarpa). Fruits, 56(5), 317-324. doi: 10.1051/fruits:2001132

Malfatti, A. D. L. R., \& Cruz, S. P. (2019). Inoculação em soja com Rhizophagus clarus produzidos em sistema de cultivo em vaso e in vitro. Scientia Agraria Paranaensis, 18(3), 244-250. doi: 10.181 88/sap.v18i3.21682

Mantovani, A. (2009). Composição química de solos contaminados por cobre: formas, sorção e efeito no desenvolvimento de espécies vegetais. Tese de doutorado em Ciência do Solo. Universidade Federal do Rio Grande do Sul, Porto Alegre, RS, Brasil. Recuperado de http://hdl.handle. net/10183/17085

Marques, D. M., Silva, A. B., Mantovani, J. R., Pereira, D. S., \& Souza, T. C. (2018). Growth and physiological responses of tree species (Hymenaea courbaril L., Peltophorum dubium (Spreng.) Taub. and Myroxylon peruiferum L. F.) exposed to different copper concentrations in the soil. Revista Árvore, 42(2), 1-11. doi: 10.1590/1806-90882018000200002

Mathur, S., Sharma, M. P., \& Jajoo, A. (2018). Improved photosynthetic efficacy of maize (Zea mays) plants with arbuscular mycorrhizal fungi (AMF) under high 
temperature stress. Journal of Photochemistry and Photobiology B: Biology, 180(1), 149-154. doi: 10.1016/j. jphotobiol.2018.02.002

McBride, M. B. (2001). Cupric ion activity in peat soil as a toxicity indicator for maize. Journal of Environmental Quality, 30(1), 78-84. doi: 10.2134/jeq2001.30178x

Miranda, J. C. C. D., Vilela, L., \& Miranda, L. N. D. (2005). Dinâmica e contribuição da micorriza arbuscular em sistemas de produção com rotação de culturas. Pesquisa Agropecuária Brasileira, 4O(10), 1005-1014. doi: 10.1590/S0100204X2005001000009

Miranda, J. C. C., \& Miranda, L. N. (1997). Micorriza arbuscular. In M. A. Vargas, \& M. Hungria (Eds.), Biologia dos solos dos cerrados (pp. 69-123). Planaltina, DF, EMBRAPA-CPAC.

Miyazawa, M., Pavan, M. A., Muraoka, T., Carmo, C. D., \& Melo, W. D. (2009). Análise química de tecido vegetal. In F. C. Silva (Ed.), Manual de análises químicas de solos, plantas e fertilizantes (Parte 2, Cap. 1, pp. 193233). Brasília, DF: EMBRAPA Informação Tecnológica.

Negrini, A. (2017). Amenizante orgânico e micorrizas arbusculares em mudas de eucalipto cultivadas em solo contaminado com cobre. Dissertação de mestrado em Agronomia - Agricultura e Ambiente. Universidade Federal de Santa Maria, Frederico Westphalen, RS, Brasil. Recuperado de https:// repositorio. ufsm.br/bitstream/handle/1/13685/ DIS_PPGAAA_2017_NEGRINI_ALEX.pdf? sequence $=1 \&$ is Allowed $=y$
Pereira, M. G., Santos, C. E., Freitas, A. D. de, Stamford, N. P., Rocha, G. S. da, \& Barbosa, A. T. (2013). Interações entre fungos micorrízicos arbusculares, rizóbio e actinomicetos na rizosfera de soja. Revista Brasileira de Engenharia Agrícola e Ambiental, 17(12), 1249-1256. doi: 10.1590/S1415-43662013001200001

Santos, H. G., Jacomine, P. K. T., Anjos, L. H. C., Oliveira, V. A., Lumbreras, J. F., Coelho, M. R., Cunha, T. J. F. (2018). Sistema brasileiro de classificação de solos. Brasília, DF: EMBRAPA Solos. (INFOTECA-E). Recuperado de http://www.infoteca. cnptia.embrapa.br/infoteca/handle/doc/ 1094003

Seidel, E. P., Costa, A. C. S. D., \& Lana, M. D. C. (2009). Fitodisponibilidade de cobre e produção de matéria seca por plantas de milho em resposta à aplicação de dejetos de suínos. Revista Brasileira de Ciência do Solo, 33(6), 1871-1878. doi: 10.1590/ S0100-06832009000600036

Silva, I. C., Rocha, C., Rocha, M. C., \& Sousa, C. M. (2018). Growth of Brachiaria decumbens in Latosol contaminated with copper. Ciência e Agrotecnologia, 42(2), 168175. doi: 10.1590/1413-7054201842203 0317

Silva, J. C. (2019). Desenvolvimento e capacidade fitoextratora de plantas agrícolas cultivadas em solo com diferentes texturas e teores de cobre. Dissertação de mestrado em Agronomia - Agricultura e Ambiente. Universidade Federal de Santa Maria, Frederico Westphalen, RS, Brasil. Recuperado de http://repositorio.ufsm.br/ handle/1/17056 
Silva, M. L. D. S., Vitti, G. C., \& Trevizam, A. R. (2007). Concentração de metais pesados em grãos de plantas cultivadas em solo com diferentes níveis de contaminação. Pesquisa Agropecuária Brasileira, 42(4), 527-535. doi: 10.1590/S0100-204X2007 000400011

Sociedade Brasileira de Ciência do Solo (2016). Manual de calagem e adubação para os Estado do Rio Grande do Sul e Santa Catarina (11a ed.). Porto Alegre: Comissão de Química e Fertilidade do Solo do Estado do Rio Grande do Sul e Santa Catarina.

Tedesco,M.J., Gianello, C.,Bissani, C.A.,Bohnen, H., \& Volkweiss, S. J. (1995). Análises de solo, plantas e outros materiais (2a ed.). Porto Alegre: Universidade Federal do Rio Grande do Sul, Departamento de Solos.

Tiecher, T. L., Soriani, H. H., Tiecher, T., Ceretta, C. A., Nicoloso, F. T., Tarouco, C. P.,... Brunetto, G. (2018). The interaction of high copper and zinc doses in acid soil changes the physiological state and development of the root system in young grapevines (Vitis vinifera). Ecotoxicology and Environmental Safety, 148(1), 985994. doi: 10.1016/j.ecoenv.2017.11.074
United States Environmental Protection Agency (1996). Method 3050 B: acid digestion of sediments, sludges, and soils. Washington, DC: USEPA.

Vieira, G. E. G., Furmigare, N. S., Teixeira, L. F., \& Colen, A. G. N. (2015). Influência da micorriza na cultura da soja: preocupação com a produção de energia-uma revisão. Revista Liberato, 16(25), 57-64. doi: 10. 31514/rliberato Recuperado de http:// www.revista.liberato.com.br/ojs_lib/index. php/revista/article/view/342

Yruela, I. (2005). Copper in plants. Brazilian Journal of Plant Physiology, 17(1), 145156. doi: 10.1590/S1677-04202005000 100012 
